\title{
The Choice of Management Accounting Techniques in the Hotel Sector: The Role of Contextual Factors
}

\author{
Ana C. Urquidi \\ Department of Accounting, Faculty of Economics, University of Valencia \\ Avenida dels Tarongers, s/n 46071 Valencia, Spain \\ Member of IMACCev (Equipo valenciano de investigación en gestión estratégica de costes) \\ Tel: 34-96-162-5199_E-mail: urquidi@uv.es \\ Vicente M. Ripoll \\ Department of Accounting, Faculty of Economics, University of Valencia \\ Avenida dels Tarongers, s/n 46071 Valencia, Spain \\ Director of IMACCev (Equipo valenciano de investigación en gestión estratégica de costes) \\ Tel: 34-96-382-8274_E-mail: vicente.ripoll@uv.es
}

Received: October 11, 2012

Accepted: January 22, 2013 Published: April 1, 2013

doi:10.5296/jmr.v5i2.2520

URL: http://dx.doi.org/10.5296/jmr.v5i2.2520

\begin{abstract}
This article analyses the management accounting techniques that are currently being used by four and five star hotels, considering the role played by contextual factors in choosing them. For this reason, we have used a qualitative and explanatory methodology, studying multiple cases. The need for adequate, concise and specific information by part of the organizations, in the current environment, has propitiated the emergence of new management techniques.
\end{abstract}

Keywords: Management Accounting, Hotel, Contingency Theory 


\section{Introduction}

During recent years the world economy has experienced unprecedented changes, a consequence of a highly complex transformation in which many forces intervene, from the dynamics of competition, the globalization of markets, the evolution of stocks, to the technological advances in the field of information and communications.

In this situation, organizations find themselves compelled to redefine the foundations of their business, and therefore to seek solutions that will permit them to survive and prosper. Information plays a primordial role in this scenario, mainly because it constitutes the basic pillar of an increasingly interconnected and globalized society.

Among the information systems par excellence are accounting systems, as they are designed to give objective and quantifiable data, on all levels of the organization. And more specifically, management accounting, a subsystem whose aim is the capture, measurement and valuation of internal circulation, as well as its rationalization and control, in order to supply the organization with relevant information for business decision making (AECA, 1990).

Management accounting has evolved in response to changes in the productive and organizational environment of the firm, showing new horizons and considerations. These aspects are found in the cost and management accounting programs of many universities. However, it is a premise in some research studies that organizations are not incorporating into their accounting practices the new techniques and tools proposed by theorists (Hansen \& Van der Stade, 2004; Pellinen \& Satinen, 2002; Rigby, 2003; Waweru et al., 2004).

The analysis of the literature indicates that business accounting practice does not adapt in the great majority of cases to the theoretical models produced by the researchers in this field (Al-Omiri \& Drury, 2007; Bescos, 2003; Lamminmaki \& Drury 2001; Spathis \& Constantinide, 2004).

This justifies the need to undertake studies to identify the management accounting techniques used and question the belief, frequent in the literature that a certain technique is used by many companies, when there is no empirical evidence of its use.

The objective of our empirical study is to know and to analyze what techniques of management accounting are currently being used, considering the role played by contextual factors in the selection of such techniques. For this we have used a qualitative and explanatory methodology, in a multiple case study.

We focus on a single economic sector, the hotel sector, as this will allow us to delimit the effects deriving from market conditions, the economic cycle and production technology.

If we analyze the hotel supply of the Valencian Region, we observe that it has experienced a steep increase in the last five years, and although the number of tourists continues to grow, and expectations are excellent, the current supply is greater than the demand, so the average occupation decreases every year. Another datum that reflects with even greater clarity the 
current situation of the sector is the average price per room, which fell by $8 \%$ last year (Generalitat Valenciana, Conselleria de Turisme).

The unchecked increase of hotel places has caused over-supply, which together with increasingly demanding customers and an inability to predict the future, have made the hotel industry have to formulate ever more complex strategies in order to achieve its objectives and to be competitive within the sector.

The changes mentioned above have caused us to opt in our analysis for the Theory of Contingency, mainly because it has been able to evolve and has incorporated variables that take into consideration the complex interrelations between the behavior of individuals as such, forming part of groups and of the organization, the formal and informal characteristics and the influence of environmental factors. Thanks to which, this theory continues to be present explicitly or implicitly in most studies into management accounting (Escobar \& Lobo, 2002).

\section{Contingency Theory}

This Theory starts from the premise of the non-existence of an internal information system applicable to all organizations and in any situation, as it will depend on the contextual factors or circumstances in which it finds itself (Otley, 1980). The Contingency Theory emphasizes that there is nothing absolute in organizations or in administrative theory. The contingent approach explains that there exists a functional relationship between the conditions of the environment and the appropriate administrative techniques for achieving the organization's goals.

Its foundations can be expressed in the following points:

- $\quad$ The structure and functioning of the organization will depend on characteristics such as technology, strategy, size and other external factors (Scott, 1987).

- $\quad$ The most important concept introduced by this approach is that of the fit between structural and environmental variables. This is a necessary, but not sufficient condition for performance to improve in terms of effectiveness and efficiency. This hypothesis, however, has been strongly criticized for having been insufficiently and inadequately tested (Scott, 1987).

\subsection{Environment}

The environment is everything that stands outside the boundaries of the organization and where its managers have no capacity of influence or control. Given which, it can be affirmed that knowing the environment in which an organization carries out its activity is a decisive factor when choosing the accounting information system (Chenhall \& Morris, 1986).

Thus the information provided by management accounting will become a key factor in decision making. The relationship between environment and management accounting has been dealt with in the literature from several perspectives. Studies such as those by Chenhall \& Morris (1986); Chong \& Chong (1997); Gordon \& Narayanana (1984); Gul \& Chia (1994) analyze the need for information systems of much broader scope in uncertain environments. 
Paulatos \& Paggios (2008), value the appropriateness and utility of information in order to face all possible changes in the environment. Chong (1996) and Fisher (1996) emphasize the use of participative budgets, while Otley (1978) recommend the need to use sophisticated accounting systems. Other authors such as Baines \& Langfield-Smith (2003); Haldma \& Lääts (2002); Khandawalla (1972) and Otley (1980) study the use of non-accounting measures in uncertain environments.

In accordance with the above studies we can confirm that environmental uncertainties have been associated with the need for more open information systems, outward-looking and providing both financial and non-financial data (Chenhall, 2003). Our first hypothesis is, therefore, as follows:

H1. The increase in levels of competition is significantly related to the use of management techniques.

\subsection{Strategy}

The influence of strategy when choosing the system of accounting information is evident from the use of terms like "strategic management accounting" or "total quality strategies" (Langfield-Smith, 1997).

The type of strategy adopted by the firm will condition the accounting information system chosen (Miles \& Snow, 1978). Firms that follow a strategy of leadership in costs will place greater importance on the cost of the product and tend to implement information systems that help to calculate and control it (Langfield-Smith, 1997; Miles \& Show, 1978; Miller \& Friesen, 1982; Porter, 1985), while organizations that follow a strategy of differentiation give more importance to the search for new markets, products or services to meet customers' needs. They therefore tend to implement accounting information systems that permit them to develop strategic objectives and facilitate customers' satisfaction (Abernethy \& Brownell, 1999; Anderson \& Lanen, 1999; Ateljevic, 2007; Baines \& Langfield-Smith 2003; Callahan \& Gabriel, 1998; Chenhall \& Langfield-Smith, 1998; Chenhall \& Morris, 1986; Davila, 2000; Dent, 1990; Jeremias \& Gani, 2004; Miles \& Snow, 1978; Miller \& Friesen, 1982; Van der Stede, 2000).

On the basis of the above studies we put forward the following hypotheses:

H2a. The use of a strategy of differentiation is significantly related to the use of the following techniques: quality management, balanced score card, knowledge management and segmentation of customers.

H2b. The use of a strategy of leadership in costs is significantly related to the use of the following techniques: traditional calculation of costs, and budgetary control.

\subsection{Size}

The size of the firm is an organizational characteristic which, in the case of hotels, is difficult to modify. Greater size brings with it a greater volume of assets, and the economic consequences of the management of these assets, both positive and negative, are more 
notable. For this reason, larger firms usually require more professionalized management and better qualified managers.

The number of rooms is the measure most commonly accepted as indicator of the size of hotels (Breiter \& Bloonquist, 1998; Garcia-Falcon \& Medina-Muñoz, 1999; Jones, 2002; Lee-Ross \& Ingold, 1994; Okoroh, et al., 2002; Pestana \& Mascarenhas, 2004; Sundgaard, et al., 1998).

Size is a variable that influences both the organization's knowledge of new management techniques and their implementation. Organizations of larger size need more sophisticated control and information systems (Ask \& Ax, 1992; Bruns \& Waterhouse, 1975; Innes \& Mitchell, 1994; Khandwalla, 1972; Merchant, 1981). Another reason given in relation to size and the use of information systems is the availability of resources mainly because the knowledge and implementation of information systems require time and money (Chenhall \& Langfiel-Smith, 1998, Hoque \& James, 2000; Hussain \& Hoque, 2002; Innes \& Mitchell, 1995; Kajüter \& Kulmala, 2005; Shield, 1997; Wareru et al., 2004). Furthermore the growth of organizations is causing problems of control, and organizations need ever more and better information, so it will be those of largest size that will employ most sophisticated management techniques (Abdel-Maksoun, 2004). We therefore develop the following hypothesis:

H3. The size of the organization significantly influences the use of new management techniques.

\section{Research methodology}

The empirical study was carried out using a qualitative approach, which permitted us to capture the heterogeneity and the range of variation existing in a certain population. We consider the organization as a whole, taking into account in the analysis its own context, trying to understand the events that occur in it and seeking authenticity and the analysis of the complexity of the case being studied (Beach et al., 2001).

The selection of cases was carried out so as to enable us to gain the best possible knowledge of the phenomenon being studied, and offer the opportunity to learn. This was achieved to the extent that there is easy access to the cases, a high probability that there is a mixture of processes, programs, people, interactions and/or structures related to the research questions and the quality and credibility of the study is ensured (Eisenhardt, 1989).

On the above basis, the hotel sector was considered suitable for this study, for the reasons given.

The profile of the organizations participating in the case study are shown in Table 1. 
Table 1. Descriptive data of the selection of cases

\begin{tabular}{|l|l|l|l|l|}
\hline Firm & No of rooms & Location & Category & Chain \\
\hline A & 522 & Beach & 5 & No \\
\hline B & 200 & City & 4 & Yes \\
\hline C & 84 & City & 5 & No \\
\hline D & 82 & City & 4 & Yes \\
\hline
\end{tabular}

The data was gathered taking into account a series of principles that help to increase the quality of the study (Yin, 1994). On the one hand, with the aim of achieving reliability in the study, we followed a protocol and drew up a database where the evidence obtained was gathered. On the other hand, to achieve the internal consistency of the study, and thus its credibility and objectivity, we used multiple information sources, established a chain of obtaining of evidence and carried out a continual review of all the reports obtained.

The interview, the direct observation and the analysis of texts and documents related with the phenomenon being studied are the principal data-gathering methods for qualitative research.

The data was assigned according to the categories presented in Table 2

Table 2. Variables

\begin{tabular}{llll}
\hline Principal variables & Second order variables \\
\hline General Characteristics & $\bullet$ & Size of the organization \\
\hline Environment & $\bullet$ & & \\
\hline & information required to perform a task, and the quantity of \\
& $\bullet$ & etc.) & Difference between the quantity of \\
& $\bullet$ & institutions & Number of different products or markets \\
\hline Strategy & $\bullet$ & Support from public or private \\
\hline
\end{tabular}




\subsection{Case A}

Case A is that of an organization with 522 rooms, located on the coast, of 5-star category, with no contractual links to hotel chains.

The specific environment, which generally affects firms with similar characteristics, is currently highly competitive due mainly to uncertainty over the evolution of demand and the ever-increasing competition.

But in the opinion of those interviewed, this is positive for the organization. As one of the respondents explains: "Firms are constantly competing. To leave the market is to perish as an organization. Obsolete establishments are out of the market, except in situations of maximum demand, which is not the current situation”.

With respect to the evolution of demand they foresee a "positive evolution" as they perceive an increased dynamism of tourism activity as the year progresses. But they maintain flexibility in the staff so as to be able to cover the different levels of hotel occupation that may occur throughout the month.

The hotel has been in operation for over 20 years. This has favored it being clearly positioned in the market. So, this organization's starting situation is comfortable, as it has a consolidated market share. Its main objective is therefore to maintain its share, and for this it uses a strategy of differentiation, trying to optimize the satisfaction of the customer at all times, creating a culture of service throughout the organization. Since they sell quality and image, they are not interested in competing on price.

Communication within the firm is informal: decisions are based on the personal relationship between the manager and his subordinates, through an unregulated exchange that arises from the consensus among the members of the organization.

Thus tasks are assigned to the heads of the functional areas, who are responsible for preparing and directing the meetings of their team. These meetings are usually held with a frequency of two to three times a month, according to need. In them the participation of all the members is stimulated, through the exposition of suggestions to solve any problems posed.

The hotel under study uses costing systems of narrow scope, cost accounting is integrated into financial accounting. Its main aim is to determine profitability by services and activity centres, using a variable cost system as method of allocation. The different centers that form the organization is responsible for drawing up their own annual budget, which are subsequently integrated and approved by the General Management. Since the main aim of the budget is the valuation of results, every week the real results obtained are compared with the budget, analyzing and attempting to correct any deviations that may have occurred. However, even if there are wide divergences between the two sets of figures, the original budget is not modified.

Of the new management techniques, they use quality management and segmentation of customers. In relation to quality management, the organization possesses ISO 9.000 
certification for all the services that it performs, and is currently applying for the $Q$ of Tourism Quality, certified by the Institute for Spanish Tourism Quality (ICTE). In order to obtain the ISO 9.000 they took advantage of the subsidy granted by the Regional Department of Tourism.

Moreover, people from outside the establishment carry out an internal quality audit every year. In this sense, the Head of Quality believes that "there is no question of economizing on this matter and how much it costs is irrelevant. Part of the normal work of any organization is to check that things are being done well”.

They also consider it fundamental to carry out a segmentation of customers, since knowing the visitor and knowing what he or she expects from the establishment, will enable them to differentiate the offer and achieve the organization's objective of customer loyalty.

\subsection{Case B}

Case B is that of an organization with 200 rooms, located in the city, with a category of four stars, linked to a hotel chain.

Their perception of the environment is characterized by increasing instability, with a constant increase in supply, not only within the Valencia Region, but worldwide. New tourism destinations are constantly appearing, made accessible to consumers thanks to the low-cost airline companies, and becoming direct competition for our destination. Although in their opinion, increased supply is not a bad thing, as it forces a continuous search for new opportunities, playing with new values that will permit the firm to reach its principal objective: satisfying the needs or expectations of its customers.

Despite the present competition, the organization has gained market share every year since its establishment in Valencia in 2001, maintaining the expected profitability.

But the future looks uncertain; even though all the expectations of growth in demand are being fulfilled, its future evolution is unknown, and this, together with the fact that the current model of growth of hotel establishments is not sustainable, may motivate a price war among hoteliers that will not benefit the sector, mainly because returns would fall or the quality of services would suffer.

Jobs are highly standardized and communication tends to be formal, due mainly to the existence of mechanisms created and recognized officially to channel information. That is to say, communication takes place through the channels and documents established for that purpose. However, since this is a matter of performing a service, not all possible events can be foreseen, and for this reason the workers have autonomy and capacity to make decisions when faced with unforeseen problems.

Customer satisfaction is the strategy followed by this organization. As they point out in the interview:

"In a hotel, the product is a room and the services are the welcome, the information, the experience in the restaurant, etc. To beat the competition you have to concentrate on the 
items that constitute added value for the customer. And you always have to ask yourself: Is it possible to increase the value for the customer?”.

The organization has a department dedicated to Management Accounting. The internal information system it uses is independent of financial accounting, using a radical dualism. The method employed for the classification of costs is that of variable cost, differentiating costs into fixed, variable and semi-variable. We cannot speak of an activity-based costs system (ABC), but their system is very detailed. They calculate the cost of all the services that they perform, since their aim is to reduce all unnecessary costs. For example, they have eliminated all the natural plants in reception as they involved a cost and their utility is little valued by the customers. We consider that starting from the costs system that they are using, with a little more specification an ABC could be implemented.

As indicated above, this organization belongs to a worldwide hotel chain. The different continents are organized by areas, the area corresponding to the Valencia Region is formed of all the hotels of the chain located in Europe, the Middle East and Africa. The budget is drawn up in various stages. In the first stage the General Management of the area transmits general instructions, for the head of each department to design its plans, programs, and budgets, on the basis of the lines proposed. In a second stage it is the departments who draw up their own budgets, on the basis of the guidelines laid down by the General Management. Finally, these budgets are integrated, first at the establishment level, then at regional level and finally at area level. We can therefore affirm that the negotiation is a process that goes from bottom to top.

The budget is incremental, based on that of the previous year. The degree of achievement of the objectives is monitored every week, comparing the evolution of each of the variables that have configured it with the results obtained. This monitoring permits the correction of unfavorable situations and actions, and if necessary the new forecasts that may derive from the new context are fixed every six months.

The quality system used is internal to the whole hotel chain, so they do not have any official recognition. It is based on the implementation of processes and focused on standards of functions of departments and, in the words of the Director of Human Resources and Head of Quality "is practical and simple”. The employees can use a telephone number to communicate their ideas on any improvement to the department, these ideas are subsequently analyzed from the point of view of their viability and their applicability to the organization. If the ideas pass the latter phase they are implemented. The result is highly satisfied on the part of the employees, who feel that they are listened to and valued, and satisfaction among customers, since the ideas put into practice have the aim of improving the quality of service.

It has an internal benchmarking, in which the processes undertaken by the different establishments of the same hotel chain are compared, to subsequently be able to apply them in those hotels that wish to do so. This method enhances "looking outwards", seeking original solutions, and permits consideration of different options that have already been tried successfully in other organizations. In addition, they are considering a competitive 
Benchmarking, based on mutual agreement between the two organizations. The disadvantage of this model lies in the need to share confidential information with the competition.

The organization uses a balanced score card, formed by a set of indicators linked to the key factors of the hotel. Among the indicators we can highlight: year-on-year growth of the market, percentage of total occupation, impact derived from occupation, income ratios, variations in staff costs, satisfaction of customers, etc.

\subsection{Case C}

This is an organization with 82 rooms, in a non-coastal location, with a five star category, not linked to hotel chains.

With respect to the generic environment in which they carry out their activity, they highlight the uncontrolled growth of supply, due to the lack of planning. In the respondents' opinion, the solution to this problem passes though a sustainable growth of supply, the adoption of policies and taxation measures favorable to the hotel industry, and continuous improvement of the location's accessibility.

However in the specific case of this establishment, they consider that the location and the product that they offer - it is near a golf course and offers spa services -- is sufficient guarantee to make them leaders in the business segment.

The organization is aware of the importance of information for the participation of the employees. They start from the premise that the employees cannot understand how the process functions unless they receive information, nor can they improve it through their contributions. Without information, the workers are limited.

The most important concepts are efficiency, productivity and quality. To achieve them, they have opted for a light and flexible structure, which can respond easily to changes in the market.

With a vision of the future, the organization has decided to implement an exploratory strategy, based on the search for opportunities, developing new services to satisfy customers' needs, bringing the maximum quality to the services performed.

As one of the respondents explains: "Any product that today is an innovation, tomorrow will have hundreds of competitors, and with time will become just one more. This implies competing with ever-narrower margins”.

To develop this strategy, the organization has needed to have available information on its activities and their cost, as well as on the services that it performs. This has generated a total predisposition to develop an activity-based costs system (ABC), from both the point of view of calculating costs and that of management of activities.

The organization presents an organic costs system, where indirect costs are allocated to the services through different work units. Both running and commercial costs are incorporated into the product /service. The explanation is based on the importance of publicity costs in 
respect of some of the services, and if they disregard this type of costs, in their opinion, they are falsifying the reality and hindering decision making.

They develop a budget by programs, preparing it by areas of responsibility: sales, staff, costs and expenses, finance, etc. Each cost centre or revenue centre is an area of responsibility, but the inverse is not necessarily true, i.e. there are areas of responsibility that are not cost centers. Subsequently they will be integrated by the General Management. In order to draw up this type of budget there is a continual exchange of knowledge, which implies not only communication between subordinates and superiors in the process of budgetary adjustment, but also a dialogue throughout the process, as with the deviations that may arise the budget has to be adapted continually to the new needs or behaviors.

Information thus circulates upwards, so the managers hear the voice of the employees, as well as horizontally, in the sense of communication with customers and suppliers; this is the only way to achieve all the objectives set by the organization.

They have a quality self-assessment model, which permits them to establish the strengths and weaknesses of the organization, average valuations of the activities performed and possible areas of improvement. It also informs about the situation of the critical variables of the establishment, indicating the paths for continuing to improve. They have not received any type of subsidy for the implantation of this quality system.

They have also carried out a study for the implantation of an activity-based costs model (ABC). But for the moment, only the analysis of the activities has been carried out. It has identified the activities and procedures of the organization aimed at converting labor and other resources into services, distinguishing activities that generate added value from those that do not, and subsequently determining the cost inductors of these activities. However it has not yet been implemented.

\subsection{Case D}

This is an organization with 84 rooms, located in the city, with four stars, linked with a hotel chain.

Though aware of the recent increase in hotel supply in the Valencia Region, they do not consider it a problem, as for now the demand is increasing at the same rate, which has permitted them to maintain their average levels of occupation for the 10 years that the hotel has been in the market.

In the respondents' opinion, the problem is the lack of “coordination” currently existing between public bodies and the hotel sector. This is due to the growth of supply, which is occurring in a disorderly and inefficient manner, and may lead to the dissatisfaction of customers, who will end up moving to other markets.

The strategy of the organization is one of differentiation, as in the respondents' opinion, in environments as competitive as those of today, it is the only possible tool to create an effective competitive advantage. It therefore belongs to the category of "Hotels with Charm". 
Hotels with Charm are very welcoming establishments, generally small, of exceptional beauty and character. Normally, they are located in inland areas (sometimes in remote places), which permit the visitor to enjoy a natural and historic environment with exceptional and highly personalized service.

Furthermore the organization is not interested in competing on prices, although the increase in hotel places is compelling the entrepreneurs of the sector to reduce their tariffs in order to capture a greater number of customers, as they consider that this measure is of little benefit and prefer to sell quality at the price that they have set, rather than reduce prices with the consequent loss of quality.

This organization allocates costs by means of a variable costs system, keeping the financial accounting independent of the cost accounting. It could be described as a broad scope system of calculation of costs, as they calculate costs and results for each of the different departments and the services that they perform.

Budgets are dawn up annually by the General Management, and then the heads of the different departments are charged with planning the different alternatives or actions to be taken in order to achieve the objectives set. And it is through a negotiation, with successive iterative phases, between the General Management and the heads of the departments that the definitive budget is shaped. It can be affirmed that the negotiation is a process that goes from bottom to top, because each of the hierarchical levels consolidates the different plans, programs and budgets accepted at previous levels. In this way the motivation and involvement of the employees is achieved, as they are made participants in the department's objectives and their proposals are listened to.

The general information on the firm's results, though it does not help participation directly, does demonstrate to the employees that they are being treated as an important part of the organization and that for this reason it shares valuable information with them. The information on the evolution of the firm and future planes must be shared between managers and front-line employees so that the latter can identify with the firm and aim to achieve the objectives.

As for new management techniques, the organization uses both financial and non-financial indicators, with the aim of measuring consumer satisfaction, maintaining regularity in productivity levels and achieving sustainable growth in the market share.

One of the tools most used by the organization is the segmentation of customers. Thanks to it, the organization can treat customer information effectively and efficiently and design and implement the strategy oriented towards encouraging the customer's retention and loyalty. This tool also permits the organization to provide the customer with an optimum level of quality, adapted to his or her expectations.

The organization is not interested in obtaining quality certifications. In the respondents' opinion, quality certifications measure the correct working of the productive process and not the customer's satisfaction, and even though a process has been correctly executed, this does 
not imply that it satisfies the consumers' expectations, hence they are not interested in this type of accreditation.

\section{Results and conclusions}

Analyzing the time perspective used by the organizations, we find that they all use a system of real or historical costs, determined ex post.

With regard to the objectives pursued by internal accounting, we have indeed found differences. The managers in case A only aim to calculate the costs of the different products or services that they provide, and the consequent result of their sale. In cases B, C and D, the main objective was to obtain information relevant to decision making. Among the decisions, we highlight in case $\mathrm{B}$ the reduction of all activities or costs that do not add value to the product, and in cases $\mathrm{C}$ and $\mathrm{D}$ the determination of the prices of new services or products offered by the establishment.

The variable cost or "direct costing" method is the most used. However there are organizations that are considering new methods such as activities-based costing (ABC).

The budgetary system used in all the organizations analyzed is based on the annual budget. The principal objective is the planning of all the activities that the firm will engage in over the year, making periodical comparisons between the budget and the reality in order to monitor and evaluate the quantitative and qualitative results, and to be able to take the appropriate corrective measures that will permit improvement of management results.

As a similar characteristic, we can observe in all the organizations the use of quality management systems. This is for two reasons. The first refers to the sector investigated, as its principal activity is service, and in this type of activity quality is important to meet customers' needs. The second is the strategy of differentiation chosen by the organizations, since through quality the differences between the organization and the competition can be established.

The segmentation of customers is the second most used technique, as they consider it important to know what the customer expects of the establishment, to be able to offer it to him or her.

And finally, three of the four firms analyzed present a set of indicators, both financial and non-financial, among which we would highlight year on year growth of the market, percentage of total occupation, impact derived from occupation, revenue ratios, variations in staff costs, customer satisfaction, among others, aimed at providing them with information for decision making.

On the above basis we consider $\mathrm{H} 1$ to be totally validated, as the organizations analyzed, in the face of increased competition, are aware of the need for adequate, concise and concrete information, for which they use different management techniques, principally variable costing, segmentation of customers and total quality management,. 
Organizations that base their strategy on differentiation must stress the aspects relating to customer orientation, notably quality, flexibility and constant innovation in products. To achieve this, they principally use quality management techniques, balanced score card, knowledge management and segmentation of customers. So we can affirm that hypothesis H2a is confirmed.

Hypothesis H2b is validated partially, because we have only one organization that follows a strategy of leadership in costs.

It is reasonable to infer that the size of the organization will influence the internal information systems used. However, this relationship has not been proved in our study. Thus H3 which related the size of the organization to the use of management techniques was rejected in our model as it presented low reliability, though in similar studies it has emerged as a relevant variable (Byrda et al., 2005; Innes \& Mitchell, 1994).

We believe that this study served at last two relevant final results. Firstly, holistically considered, the finding provides support for the application of the contingency theory in the system accounting design; we analyzed the way in which the strategic, the environment, size and management accounting practices are combined to enhance performance.

Secondly, our study has revealed insights referred to the way management accounting is deployed, in view of the considerable amount of publicity that has been given over the past 10 years to apparent limitations of traditional cost system and the urgent need for organizations to change their management accounting system, it is a key factor to determine why most firms have been reluctant to change their systems. Further empirical studies are taken to provide a detailed description and evaluation of these new systems and the factor that influenced the change.

\section{References}

Abdel-Maksound, A.B. (2004). Manufacturing in the UK: contemporary characteristics and performance indicators. Journal of Manufacturing Technology Management, 15(2), 155-171.

Abernethy, M. A., \& Brownell, P. (1999). The role of budgets in organizations facing strategic change: an exploratory study. Accounting, Organizations and Society, 24, 189-204. http://dx.doi.org/10.1016/S0361-3682(98)00059-2

AECA. (1990). El Marco de la Contabilidad de Gestión. Serie Principios de Contabilidad de Gestión., Documento n ${ }^{\circ} 1$.

Al-Omiri, M., \& Drury, C. (2007). A surrey of factors influencing the Choice of product costing Systems in UK organizations. Management Accounting Research, 18, 399-424. http://dx.doi.org/10.1016/j.mar.2007.02.002

Anderson, S \& Lanen, W. (1999). Economic transition, strategy \& the evolution of management practices: the case of India. Accounting Organizations and Society, 24, 379-412. http://dx.doi.org/10.1016/S0361-3682(97)00060-3 
Ask, U., \& Ax, C. (1992). Trends in the development of product costing practices and techniques. Paper presented to the European Accounting Association Annual Congress, Madrid, Spain.

Ateljevic, J. (2007). Small tourism firms \& management practice in New Zealand: the centre stage macro region. Tourism Management, 22, 307-316.

Baines, A., \& Langfield-Smith, K. (2003). Antecedents to management accounting change: a structural equation approach. Accounting Organizations and Society, 28, 675-698. http://dx.doi.org/10.1016/S0361-3682(02)00102-2

Beach, R., Muhlemann, A.P., Price, D.H.;Paterson,A, \& Sharp, J.A.(2001). The role of qualitative methods in production management research. International. Journal of. Production Economics, 74, 201-212.

Bescos, P.L. (2003). New Tasks for Management Accounting. 2003 Management Accounting Section Research \& Case Conference. San Diego, California, january, 10-11.

Breiter, D., \& Bloomquist, P. (1998). TQM in American hotels. Cornell Hotel \& Restaurant Administration Quarterly, 39, 26-34.

Bruns, W., \& Waterhouse, J. (1975). Budgetary control and organizational structure. Journal of Accounting Research, 19, 177-203.

Byrda, T. A., Thrasherb, E. H., Langc, T., \& Davidsond, N. W. (2005). Aprocess-oriented perspective of IS success: Examining the impact of IS on operational cost. Omega, 34, 448-460.

Callahan, C. M., \& Gabriel, E. A. (1998). Information in imperfectly competitive markets: a theoretical and empirical investigation. Contemporary Accounting Research, 15(4), 419-455.

Chenhall, R.H. (2003). Management control systems design within its organizational cpntext: finding from contingency-based research and directions for the future. Accounting Organizations and Society, 28, 127-168. http://dx.doi.org/10.1016/S0361-3682(01)00027-7

Chenhall, R.H., \& Langfield-Smith, K. (1998). Adoption and benefits of management accounting practices: an Australian study. Management Accounting Research, 9, 1-19. http://dx.doi.org/10.1006/mare.1997.0060

Chenhall, R.H., \& Morris, D. (1986). The impact of Structure, Environment, and Interdependence on the Perceived Usefulness of Management Accounting Systems. The Accounting Review, 61, 16-35.

Chong, V. K., \& Chong, K. M. (1997). Strategic choices, environmental uncertainty and SBU performance: a note on the intervening role of management accounting systems. Accounting \& Business Research, 27(4), 268-276.

Chong, V.K. (1996). Management accounting systems task uncertainty \& managerial performance: a research note. Accounting Organizations Society, 21, 415-421. http://dx.doi.org/10.1016/0361-3682(95)00045-3 
Davila, T. (2000). An empirical study on the drives of management control systems' design in new product development. Accounting Organizations and Society, 25, 383-409. http://dx.doi.org/10.1016/S0361-3682(99)00034-3

Dent, J.F. (1990). Strategy, organization and control: some possibilities for accounting research. Accounting Organizations and Society, 15(1/2), 3-25. http://dx.doi.org/10.1016/0361-3682(90)90010-R

Eisenhardt, K.M. (1989). Building theories from case study research. Academy Management Review, 14, 532-550.

Escobar Pérez, B., \& Lobo Gallardo, A. (2002). Implicaciones teóricas y metodológicas de la evolución de la investigación en contabilidad de gestión. Revista Española de Financiación y Contabilidad, XXXI(111), 245-286.

Fisher, C. (1996). The impact of perceived environmental uncertainty \& individual differences on management information requirements: a research note. Accounting Organizations and Society, 21, 361-369. http://dx.doi.org/10.1016/0361-3682(95)00029-1

Garcia-Falcón, J.M., \& Medina-Muñoz, D. (1999): The relationship between hotel companies \& travel agencies: an empirical assessment of the US market. The service Industries Journal, 19(4) 102-122.

Gordon, L.A., \& Narayanana, V. K. (1984). Management accounting systems, perceived environmental uncertainty and organizational structure: an empirical investigation. $\begin{array}{lllll}\text { Accounting Organizations } \quad \text { and } & \text { Society, } & 9, & \text { 33-47. }\end{array}$ http://dx.doi.org/10.1016/0361-3682(84)90028-X

Gul, F.A., \& Chia, Y.M. (1994): The effects of Management Accounting Systems, perceived environmental uncertainty and decentralizations on Managerial Performance: a test of three-way interaction. Accounting Organizations and Society, 19, 413-426. http://dx.doi.org/10.1016/0361-3682(94)90005-1

Haldma, T., \& Lääts, K. (2002). Contingentes influencing the management accounting practices of Estonian manufacturing companies. Management Accounting Research, 13, 379-400. http://dx.doi.org/10.1006/mare.2002.0197

Hansen, S.C., \& Van der Stede, W.A. (2004). Múltiple facets of budfeting: an exploratory analysis. Management Accounting Research, 15, 415-439. http://dx.doi.org/10.1016/j.mar.2004.08.001

Hoque, Z., \& James, W. (2000). Linking size \& markets factors to balanced scorecard: impact on organizational performance. Journal of Management Accounting Research, 12, $1-17$.

Hussain, M., \& Hoque, Z. (2002). Underst\&ing non-financial performance measurement practices in Japanese banks: A new institutional sociology perspective. Accounting Auditing and Accountability Journal, 15, 162-183. 
Innes, J., \& Mitchell, F. (1994). A survey of ABC in UK's Largest Companies, Working Paper.

Innes, J., \& Mitchell, F. (1995). A survey of activity -based costing in the U.K.'s largest companies. Management Accounting Research, 6(2), 137-153. http://dx.doi.org/10.1006/mare.1995.1008

Jermias, J., \& Gani, L. (2004). Integrating business strategy, organizational configurations and management accounting systems with business unit effectiveness: a fitness landscape approach. Management Accounting Research, 15, 179-200. http://dx.doi.org/10.1016/j.mar.2004.03.002

Jones, C. (2002). Facilities management in medium-size UK hotels. International Journal of Contemporary Hospitality Management, 14(2), 72-80.

Kajüter, P., \& Kulmala, H. I. (2005). Open-book accounting in networks. Potential achievements and reasons for failures. Management Accounting Research, 16, 179-204.

Khandwalla, P. (1972). The effects of different types of competition on the use of management controls. Journal of Accounting Research, 275-285.

Lamminmaki, D., \& Drury, C. (2001). A comparison of New Zel \& British product-costing practice. The International Journal of Accounting, 36, 329-347.

Langfield-Smith, K. (1997). Management control systems and strategy: a critical review. Accounting Organizations and Society, 22, 207-232. http://dx.doi.org/10.1016/S0361-3682(95)00040-2

Lee-Ross, D., \& Ingold, A. (1994). Increasing productivity in small hotels: are academic proposals realistic? International Journal of Hospitality Management, 13(3), 201-07.

Merchant, K. (1981). The design of the corporate budgeting system: influences on managerial behaviour and performance. Accounting Review, 56, 813-829.

Miles, R.E., \& Snow, C.C. (1978). Organizational strategies, structure and process. Nueva York, NY: McGraw-Hill.

Miller, D., \& Freiser, P.H. (1982). Innovation in conservative and entrepreneurial firms: two models of strategy momentum. Strategic Management Journal, 1-25.

Okoroh, M.I., Jones, \& C. Ilozor, B.D. (2002). FM application in the hospitalito sector. Facilities, 20(7/8), 239-250.

Otley, D. T. (1978). Budget use \& managerial performance. Journal of Accounting Research, 16(1), 122-149.

Otley, D.T. (1980). The Contingency Theory of Management Accounting: Achievement and Prognosis. Accounting Organizations and Society, 5(4), 413-28. http://dx.doi.org/10.1016/0361-3682(80)90040-9 


\section{Macrothink}

Journal of Management Research

ISSN 1941-899X

2013, Vol. 5, No. 2

Paulatos, O., \& Paggios, I. (2008). A survey of factors influencing the cost system desing in hotels. International Journal of Hospitality Management, 28, 263-271.

Pellinen, J., \& Sutinen, T. (2002). Cost \& revenue management in Finnish hotel industry. Paper EAA 2002 Annual Conference. Copenhagen.

Pestana, C., \& Mascarenhas, M.J. (2004). Technical and allocative efficiency in Chain of small hotels. Hospital Management, 24(3), 415-436.

Porter, M.E. (1985): Competitive Advantage: Creating and Sustaining Superior Performance. New York: Free Press.

Rigby, D. K. (2003). Management tools survey 2003; usage up as companies strive to make headway in tough times. Strategy \& Leadership, 31(5), 4 -12. http://dx.doi.org/10.1108/10878570310492005

Scott, W.R. (1987). Organizations: Rational, Natural and Open Systems. Ed. Prentince Hall, Englegood Cliff.

Shields, M.D. (1997). Research in management accounting by North Americans in the 1990s. Journal of Management Accounting Research, 9, 3-61.

Spathis, C. \& Constantinide, S. (2004). Enterprise resource planning system impact on accounting processes. Business Process Management Journal, 10, 234-247. http://dx.doi.org/10.1108/14637150410530280

Sundgaard, E., Rosenberg, L., \& Johns, N. (1998). Typology of hotels as individual players: the case of Bornholm, Denmark. International Journal of Contemporary Hospitality Management, 10, 180-190. http://dx.doi.org/10.1108/09596119810227721

Van der Stede, W. A. (2000). The relationship between two consequences of budgetary controls: budgetary slack creation and managerial short-term orientation. Accounting $\begin{array}{lll}\text { Organizations } \quad \text { and } & \text { 60ciety, 25(6), }\end{array}$ http://dx.doi.org/10.1016/S0361-3682(99)00058-6

Waweru, N. M., Hoque, Z., \& Uliana, E. (2004). Management accounting change in South Africa. Accounting Auditing and Accountability Journal, 17(5), 675-704. http://dx.doi.org/10.1108/09513570410567773

Yin, R. (1994). Case Study Research. Design and Methods. London, Sage Publications. 